\title{
Virtuel vejledning under Corona-krisen
}

Anne Bang-Larsen, Syddansk Universitet

Ane Qvortrup, Syddansk Universitet

\begin{abstract}
Artiklen præsenterer fund og resultater fra en undersøgelse af det virtuelle vejledningsforløb i forbindelse vejledningen af gymnasieelevers større tværfaglige opgave, studieretningsprojektet (SRP) eller studieområdet (SOP) under skolenedlukninger grundet Covid-19. Fokus retter sig mod, hvordan vejledningen didaktisk udmøntede sig i det virtuelle rum og forhandles mellem aktørerne. Dette undersøges gennem en analyse af, hvad indholdet for vejledningen har været, hvordan den har formet sig, og hvilke formål der knytter sig dertil. Undersøgelsen tager elevernes perspektiv ift. de tre spørgsmål. Artiklen baserer sig teoretisk på en kommunikativ tilgang til didaktik. Metodisk er den funderet på et mixed method-design med kvantitative data fra surveys og kvalitative data fra vejledningsobservationer og interviews med elever indsamlet $\mathrm{i}$ april 2020, dvs. midt under skolenedlukningerne.

Gennem analyserne viser vi, at den virtuelle vejledning er præget af en mangfoldighed af virtuelle vejledningsformater. Analyserne peger på, et stort potentiale knyttet til brugen af de forskellige online vejledningsformater. Analyserne viser imidlertid også en uoverensstemmelse mellem de formål, eleverne knytter til de forskellige formater, og de praktikker vi kan udlede af vejledningshændelserne. Et centralt fund er, at forskelligartede forståelser af vejledningsformaters funktion er forbundet med en manglende didaktisk bevidsthed om, hvad de forskellige virtuelle vejledningsformater kan bidrage med.
\end{abstract}

\section{Engelsk abstract}

The article presents findings from research on the online supervision of Danish upper secondary school students writing their major assignment. Focus is on the didactical use of online formats in supervision and the negotiation between the involved agents. The investigation is based on analysis of the content of the supervision, how the supervision was formed and what kind of function the students attached to the supervision. Theoretically, the article is based on a communicative approach to didactics, and methodologically on a mixed method design with quantitative survey data and qualitative data. At the center of the analysis, we put the narratives of the students, and their experiences of the supervision.

Based on the analysis we find that online supervision is practiced with the use of a variety of online formats, where different formats contribute with very different aspects to the students writing processes. The analysis stresses a discrepancy concerning the students' conception of function attached to the use of different formats and practices of supervision. We conclude by addressing, that different conceptions of function are related to the lack of didactical knowledge of, how different online formats used in supervision contribute with very different aspects to the students writing processes. 


\section{Indledning}

Corona-pandemien og Ny lov og bekendtgørelse om nødundervisning satte i marts 2020 gymnasiet, lærere, elever og ikke mindst samarbejdet mellem disse under pres, da gymnasierne ligesom resten af samfundet måtte lukkes ned med få dages varsel. Samarbejdet blev presset af den digitale omstilling, som gymnasiet havde pligt til at gennemføre på få dage.

3.g'erne stod i en helt særlig situation under nedlukningen. Langt størstedelen skulle påbegynde eller var i gang med deres større skriftlige opgave: studieretningsprojektet (SRP) eller studieområdeprojektet (SOP). Disse opgaver er selvstændige, større skriftlige opgaver, som typisk involverer flere fag, og som skrives under vejledning $\mathrm{i}$ et omfang af 20 timer $^{1}$. Opgaven afsluttes med et mundtligt forsvar. Karakteren tæller med vægten 2 på eksamensbeviset, og opgaven opfattes af mange som kronen på værket af det treårige gymnasieforløb. Der er altså virkeligt noget på spil. Tidligere studier af undervisningen under Corona-nedlukningen peger på, at den digitale omstilling fører til en redistribuering af roller i undervisningen (McGuinness 2020) og til ændringer i indholdet af undervisningen (Butcher 2020, Yao et al 2020). I forlængelse heraf udtrykkes bekymring for elevernes tilknytning til skolen og kvaliteten af deres relation til voksne og jævnaldrende i skolen, som "are critical to learning and thriving in life" (Aspen Institute 2020). Ligeledes er der bekymring for elevernes faglige engagement (Clancy \& Sentence 2020). Når dette sammenholdes med et tidligere studie blandt elever og lærere på 38 gymnasier, som viser, at undervisning, der involverer digital teknologi, er den form for undervisning, hvor elever og lærere er mest uenige om muligheder og begrænsninger (Qvortrup m.fl. 2018), er der grund til at antage, at vejledningen ifm. de større skriftlige opgaver har virket udfordrende for de deltagende elever.

Med ovenstående udgangspunkt undersøger vi i denne artikel den virtuelle vejledning af elevernes skriveprocesser og deres oplevelse heraf under Covid 19-skolenedlukningerne. Med fokus på eleverne er det artiklens hensigt at besvare forskningsspørgsmålet:

Hvilke vejledningsformater har været anvendt $i$ den virtuelle vejledning $i$ gymnasiet under skolelukninger grundet Covid-19, og hvordan har eleverne oplevet disse?

Teoretisk er artiklen funderet i en kommunikativ tilgang til didaktik. Metodisk er artiklen baseret på et mixed method-design med kvantitative data fra surveys og kvalitative data fra vejledningsobservationer og interviews med elever indsamlet i april 2020, dvs. midt under skolenedlukningerne.

Vejledning af skriveprocesser har det seneste årti gennemgået mangfoldige forandringer, hvoraf en af dem knytter sig til nye online vejledningspraktikker, der supplerer og i nogen sammenhænge ligefrem erstatter den traditionelle face-to-face vejledning (Maor, Ensher, \& Fraser 2015; Bengtsen \& Jensen 2015; Kumar \& Johnson 2017). Feltet er velbelyst i forhold til de videregående uddannelser, men mindre udforsket i relation til ungdomsuddannelserne. Artiklen bibringer feltet værdifuld viden om tilgange til og erfaringer med virtuel vejledning, som den blev praktiseret på det danske gymnasieområde under den nationale nedlukning forårsaget af Covid-19. Undervisere fra ungdomsuddannelser, mellemlange og videregående uddannelser får gennem artiklen en nyttig viden om de erfaringer, eleverne tager med sig fra gymnasiet, og de făr en indsigt i de potentialer og udfordringer, der fra et elevperspektiv knytter sig til den virtuelle vejledning.

\section{Tidligere vejledningsforskning}

Forskning i vejledning af skriveprocesser knytter sig primært til de videregående uddannelser (Dysthe, Samara \& Westrheim 2006; Wichmann-Hansen, Eika \& Mørcke 2007; Halse \&Malfroy 2010; Maxwell \& Smyth 2011). Dette kan tilskrives det forhold, at både større skriftlige opgaver og kravet om vejledning 
i arbejdet med disse er af nyere dato på ungdomsuddannelserne. Når det kommer til virtuel eller online vejledning, trækkes der i vejledningsforskning ofte på Hamilton og Scanduras definition: "we define online mentoring as a developmental relationship between a more experienced individual and a less experienced protégé that is embedded within the career context and that primarily uses online media" (Hamilton \& Scandura 2003; Kumar \& Johnson 2019: 60). Relationen mellem vejleder og vejledt står centralt i denne definition, og fra forskningen ved vi, at online-tilstedeværelse giver andre betingelser for roller, relationer og kommunikation, idet tilstedeværelsen får en anden karakter (Beer \& Mason 2009; Power \& Vaughan 2010; Anthony \& Nagel 2010; Bengtsen \& Jensen 2015). Forskningen i virtuel faglig vejledning sondrer ofte mellem det fagligt udviklende element i relationen og det psykosociale element (Ives \& Rowley 2005; Lee 2008; Crawford, Randolph \& Yob 2014). I forlængelse heraf fastslår forskningen en stor variation i behovet for fokus, afhængigt af person såvel som tidspunktet i vejledningsprocessen (Gatfield 2005).

En anden del af forskningen fokuserer på forskellige kvaliteter knyttet til forskellige former for virtuel vejledning. Bengtsen og Jensen (2015) samt Suler (2004) introducerer begrebet online-formater som et medium-teoretisk perspektiv til at undersøge virtuelle vejledningsprocesser. Begrebet sigter til, om den virtuelle vejledning primært baserer sig på skriftlig online-kommunikation, audio-opkald eller video/facetime. Online formaterne kategoriseres som skriftlig asynkron kommunikation (kommunikation på undervisningsplatform, chat og mail), audio synkron kommunikation (telefon) og video synkron (teams, skype og zoom). Bengtsen og Jensen peger på, at forskellige online-formater har forskellige kvaliteter, som bør tilpasses formålet (2015: 2).

I lighed med face-to-face vejledning peger forskning i online-vejledning på betydningen af tillid i relationen (Lener \& Sitzman 2006; Yob \& Crawford 2012; Erichsen, Bollinger \& Hallupa 2014; Rademaker m.fl. 2016), både i forhold til udvikling af fagligt engagement og inkulturering af den studerende (Ives \& Rowley 2005; Lee 2008; Boud \& Lee 2009). I forhold til det faglige engagement, suppleres opmærksomheden herpå af studier af elevers self efficacy eller tro på egne evner, når det kommer til at arbejde online. Tladi (2017) skelner mellem forskellige typer af tro på egne evner: Tro på egne evner specifikt, når det kommer til distanceundervisning, tro på egne evner i forhold til selvreguleret læring, og tro på egne evner i forhold til computer- og onlineteknologier. Tilsvarende gælder det for Al Fadda (2019), der med udgangspunkt i påvisningen af en signifikant sammenhæng mellem troen på egne evner og indre målorientering, taler om self efficacy som en motiverende egenskab, når undervisningen foregår på distance. Chung (2015) påpeger en sammenhæng mellem troen på egne evner og brugen af selv-regulerede læringsstrategier i forbindelse med distanceundervisning. Wang, Peng, Huang, Hou og Wang (2008) viser også, at der er en sammenhæng mellem tro på egne evner, læringsstrategier og læringsresultater hos elever i distanceundervisning. Peck, Stefaniak og Shah (2018) finder, at tro på egne evner - sammen med indsatsregulering og peerlearning - korrelerer med fastholdelse i fjernundervisning.

Flere forskere peger i tilknytning til ovenstående på, at online vejledning tilbyder andre formater, som kan medvirke til at cementere en dialogpræget, procesorienteret og tillidsfuld relation, særligt i forhold til tekstbaseret feedback, hvor de virtuelle værktøjer muliggør vejleders adgang til skriveprocessen (Suler 2004; Kumar \& Johnson 2019; Bengtsen \& Jensen 2015). Men feltet adresserer også et behov for at gentænke vejledning af skriveprocesser $\mathrm{i}$ en virtuel kontekst i takt med den forandring, vejledningspraksissen gennemgår med den stigende brug af online værktøjer (Beer \& Mason 2009; Wisker 2005; Erichson, Bollinger \& Hallupa 2014; Bengtsen \& Jensen 2015). Dette peger på relevansen af at undersøge den kommunikative forhandling af vejledningsprocesserne, når de ændres fra fysiske face-to-face møder til online-vejledningsformater. 


\section{Teoriramme}

Som teoretisk grundlag for artiklen havde vi brug for en ramme, der gav mulighed for at indfange herog-nu-forhandlinger ift. de tre didaktiske grundspørgsmål - hvorfor, hvad og hvordan - som vi, jf. indledningens pointer omkring redistribuering af roller og ændringer i indhold, antog ville finde sted i situationen med den digitale omstilling. Vores udgangspunkt var, at lærere og elever var sat i en sitaution, hvor de elev- og lærerpraktikker, forstået som gentagne måder at gøre ting på, som var opbygget gennem de første år af elevernes gymnasietid, måtte genforhandles i lyset af den nye situation. For at kunne fange dette, tager artiklen afsæt i en kommunikativ tilgang til undervisning og didaktik, som tager hensyn til det forhold, at uddannelsessystemet undergår konstant forandring (Qvortrup m.fl. 2018). I de oprindelige forslag til den kommunikative tilgang, henvises der til forandringerne bundende i såvel globalisering og ændrede transnationale uddannelsespolitiske fokuseringer som nye videns-, kundskabs- og faglighedsformer knyttet til didaktiske ændringer i forståelsen af, hvad uddannelse er og bør rette sig mod (Qvortrup 2018). Antagelsen er, at tilgangen også kan gribe de konkrete forandringer knyttet til COVID 19-situationen. Afgørende er det for den kommunikative tilgang, at forandringerne udfordrer den selvfølgelige legitimitet ift. fag og fagkonstruktioner (Krogh 2003, 2006), idet de udgør "krefter som tvinger fag til å utvikle en uttalt og kontinuerlig endringsberedskab" (Ongstad 2006: 28), og dermed fremtvinger en kontinuerlig gentænkning af didaktikken. I udgangspunktet antages disse gentænkninger at finde sted på forskellige niveauer, på programmatisk niveau gennem gentagne udviklinger af læreplaner, på planlagt niveau, hvor læreren hele tiden må udvikle nyt indhold og nye former, reflekteret op imod et forandret didaktisk formål (Qvortrup 2018). For indeværende havde vi dog fokus på de gentænkninger, som fandt sted på didaktisk praksisniveau, hvor det nye indhold, de nye former og de forandrede didaktiske formål forhandles i den didaktiske praksis. Rammen herfor findes i følgende model til analyse af didaktiske hændelser (Figur 1), der er udviklet i regi af projekt "Faglighed og skriftlighed" (Christensen m.fl. 2014: 34-44), men hos Qvortrup m.fl. (2017) og Qvortrup (2020a) er generaliseret til didaktiske hændelser i bred forstand.

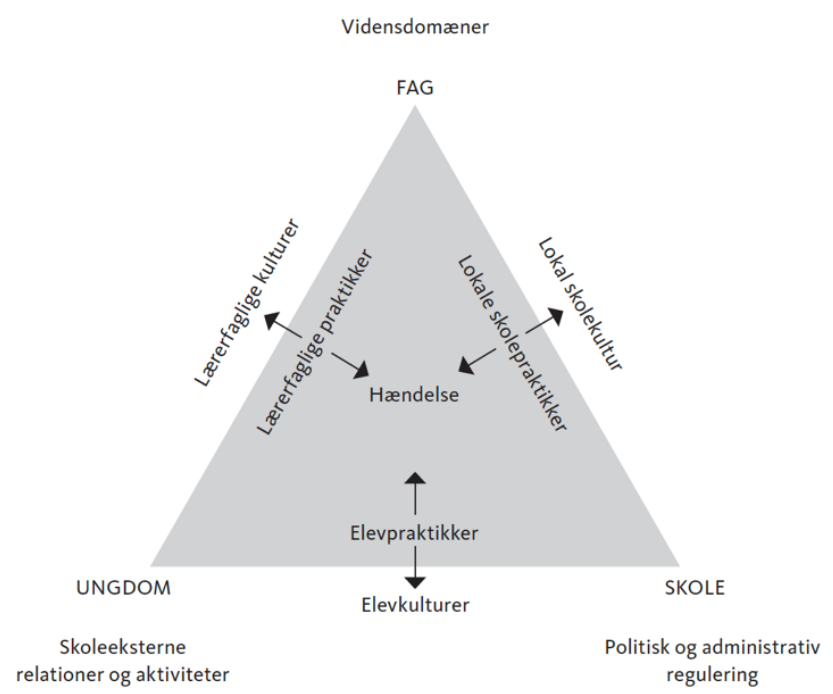

Figur 1: Model til analyse af didaktiske hændelser

Modellen har et kommunikationsteoretisk udgangspunkt, men fungerer også som en sociologisk model med fokus på aktører og deres positioner i didaktiske hændelser (Christensen m.fl. 2014). En didaktisk hændelse forstås som en social hændelse, hvor der interageres med forholdene i en given situation (her fx vilkårene knyttet til Covid-19-situationen). Hændelser betegner observerbare situationer i undervisningen (Christensen m.fl. 2014), og modellen viser, hvordan sådanne hændelser reflekterer praktikker og kulturer i forhold til såvel studerende som undervisere og den konkrete institution. Praktikker forstås som generelle kulturelle måder at gøre didaktiske praksisser på. De refererer til 
kulturelle normer, værdier, holdninger og sociale relationer, og kan ikke direkte observeres i en konkret situation, men de kan analytisk fanges som genkommende måder, teknikker og mønstre, som hændelser får mening igennem, og som også sætter grænsen for, hvad der er legitimt og anerkendelsesværdigt (ibid.). Ud over at referere til normer, værdier, holdninger og sociale relationer, indfanger kulturer de grundlæggende antagelser, som findes blandt og skabes af institutionens aktører, men også rammesættes af teknologier, materialer og fysiske rammer (ibid.).

Det kommunikationsteoretiske kender vi fra fx Ongstad (2013), som har fokus på den måde, hvorpå fag, uddannelse og undervisning i lyset af det udtalte og kontinuerlige forandringsberedskab forhandles og designes gennem kommunikation "mellom gitt og nytt, tradisjon og fornyelse, produkt og prosess" (Ongstad 2013: 28). Ifølge Ongstad er den kommunikative designproces "triadisk i sitt skille mellom, og kobling av, tekstens eller ytringens form, innhold og bruk" (Ongstad 2013: 34). I didaktiske termer er der tale om de tre grund-hv-spørgsmål: hvad skal der undervises i (indhold), hvordan skal dette indhold præsenteres (form) og hvorfor/med hvilket formål (funktion/brug). For at fange det foranderlige tilføjer Ongstad (2013) desuden de to kategorier tid og sted: "Kronotop, forstått som fysisk tid-og-sted, bliver [...] en uunngåelig og alltid tilstedeværende og taus kontekst" (Ongstad 2013: 35). Fag, uddannelse og undervisning, dvs. didaktik, må "alltid forholde seg til fem grunnaspekter som alle er innvevd i hverandre, nemlig form, innhold, bruk, tid og sted" (Ongstad 2013: 35). I den didaktiske designproces, som udspiller sig kommunikativt, beskriver Ongstad (2013) didaktisering, som:

"skjer gjennom ulike prosesser og mekanismer som reformer, fagkritikk, fundamental fagtvil, forskning mer generelt, konkrete forskningsprogrammer, semiotisk bevissthet om kunnskap og læring som tegn (semiose som ny mening), erkjennelsen av kunnskapens relativitet (postmoderne og poststrukturalisme), særkunnskapens infiltrering i livets mange sider, økt innsikt i fagspråket og fagtekstene ("den diskursive vending"), utvikling av didaktikk som eksplisitt filosofi og vitenskapsteori." (Ongstad 2013: 36).

\section{Metode}

Artiklen er baseret på et mixed method design med kvantitative data i form af surveys til elever fra 11 gymnasier, der som et ud af 8 temaer undersøgte elevernes arbejde med SOP/SRP under nedlukningen foråret 2020 (Qvortrup 2020b). Ud af den samlede respondentgruppe på 3342, svarede 677 3.g'ere på den sidste del om SRP-/SOP-opgaven. Som det fremgår af nedenstående tabel 1 over elevernes status på arbejdet med SRP'en/SOP'en på undersøgelsestidspunktet, var 488 elever (72,1\% af 3.g'erne) i gang med eller havde afsluttet SRP'en/SOP'en. Det er disse besvarelser, der danner grundlag for analyserne i denne artikel.

Tabel 1: 3.g-elevernes svar på spørgsmålet: "Hvor langt er du i forhold til SRP'en/SOP'en?"

\begin{tabular}{|l|l|l|}
\hline & Respondenter & Procent \\
\hline $\begin{array}{l}\text { Jeg er endnu ikke startet på } \\
\text { den }\end{array}$ & 2 & $0,3 \%$ \\
\hline Jeg er i gang med den & 50 & $7,4 \%$ \\
\hline $\begin{array}{l}\text { Jeg afsluttede den inden } \\
\text { karantæenen }\end{array}$ & 187 & $27,6 \%$ \\
\hline $\begin{array}{l}\text { Jeg afsluttede den under } \\
\text { karantænen }\end{array}$ & 438 & $64,7 \%$ \\
\hline I alt & 677 & $100,0 \%$ \\
\hline
\end{tabular}


De kvantitative data suppleres med kvalitative data fra et casestudie (Yin 2003) af vejledning af ni elevers arbejde med SRP'en, indsamlet i marts-april 2020'. Mixed method-tilgangen er karakteriseret ved 'diversity of views' eller 'perspective change' og 'complementation', cf. Green's og Bryman's taksonomier for mixed methods design (Greene et al. 1989, Greene 2007, Bryman 2006). Med hensyn til skiftet i perspektiver, er det hensigten at øge både bredden af og dybden i vores analyser af elevernes oplevelse af, hvordan vejledningen har formet sig, ved at analysere fra forskellige perspektiver eller paradigmer. Med hensyn til komplementariteten søger vi at udvide vores perspektiv ved at kombinere forskellige datakilder.

I caseundersøgelsen er ni elever fra fire forskellige skoler fulgt tæt gennem deres arbejde med SRPopgaven. De fire skoler repræsenterer en geografisk og størrelsesmæssig spredning, og eleverne repræsenterer både en køns-, præstations- og fagmæssig spredning udvalgt ud fra princippet om maksimal variation (Cresswell 2013). Ud fra ønsket om at frembringe relativt tykke data (Geertz 1973) er følgende indsamlet: opgaveinstruks, elevnoter og elevens færdige aflevering; optagelse af virtuel vejledning (video såvel som audio); skriftlige kommunikationstråde mellem vejleder og vejledte (emails $\mathrm{mm}$.); skriftlige virtuelle delinger af opgaveelementer og eventuel feedback. Det indsamlede datamateriale ligger til grund for afholdelse af individuelle elevinterviews, afviklet med afsæt i Lillis interviewmetode talk-around-the-text-interviews (Lillis 2009). Fokus for disse interviews er elevens udpegning af passager i opgavedokumentet, som interviewet tager sit afsæt $i$, hvorved interviewedes perspektiv privilegeres, og man får adgang til relativt fyldige narrativer. Oversigt over det kvalitative datamateriale præsenteres i tabel 2:

Tabel 2: Oversigt over datamateriale

\begin{tabular}{|c|c|c|c|c|c|c|c|}
\hline Elev & $\begin{array}{l}\text { Psedo } \\
\text { nym }\end{array}$ & Skole & $\begin{array}{l}\text { Tema } \\
\text { for } \\
\text { SRP }\end{array}$ & Fag & $\begin{array}{l}\text { Data, } \\
\text { Tekster }\end{array}$ & $\begin{array}{l}\text { Data, } \\
\text { vejledning }\end{array}$ & $\begin{array}{l}\text { Data, } \\
\text { inter- } \\
\text { views }\end{array}$ \\
\hline 1 & Mie & $\begin{array}{l}\text { Nords } \\
\text { kolen }\end{array}$ & $\begin{array}{l}\text { Politisk } \\
\text { kommu } \\
\text { ni- } \\
\text { kation }\end{array}$ & $\begin{array}{l}\text { Samf. A } \\
\text { og Eng. } \\
\text { A }\end{array}$ & $\begin{array}{l}\text { Opgave instruks. } \\
\text { Elevnoter efter } 3 \\
\text { og } 9 \text { dages arb. } \\
\text { Elevnoter fra } \\
\text { vejledning. } \\
\text { Færdige opgave. }\end{array}$ & $\begin{array}{l}\text { Observation af } 1^{*} \\
\text { gruppevejledning } \\
\text { forud for } \\
\text { nedlukning. } \\
\text { Observation af } 2^{*} \\
\text { online vejledninger } \\
\text { (Messenger- } \\
\text { opkald). } \\
7^{*} \\
\text { mailkorrespondanc } \\
\text { er. }\end{array}$ & 2 stk. \\
\hline 2 & Marius & $\begin{array}{l}\text { Nords } \\
\text { kolen }\end{array}$ & $\begin{array}{l}\text { Det } \\
\text { retfærdi } \\
\text { ge } \\
\text { samfun } \\
\text { d }\end{array}$ & $\begin{array}{l}\text { Dansk A } \\
\text { og Samf. } \\
\text { A }\end{array}$ & $\begin{array}{l}\text { Opgave instruks. } \\
\text { Elevnoter efter } 5 \\
\text { dages arb. } \\
\text { Elevnoter fra } \\
\text { vejledning. } \\
\text { Færdige opgave. }\end{array}$ & $\begin{array}{l}\text { Observation af } 1^{*} \\
\text { gruppevejledning } \\
\text { forud for } \\
\text { nedlukning. } \\
2^{*} \text { mailkorresponda } \\
\text { ncer med vejleder. }\end{array}$ & 1 stk. \\
\hline 3 & Luna & $\begin{array}{l}\text { Sydsko } \\
\text { len }\end{array}$ & $\begin{array}{l}\text { Religion } \\
\text { sundertr } \\
\text { ykkelse i } \\
\text { Kina }\end{array}$ & $\begin{array}{l}\text { Samf. A } \\
\text { og Rel. } \\
\text { C }\end{array}$ & $\begin{array}{l}\text { Opgave instruks. } \\
\text { Elevnoter efter } 7 \\
\text { og } 9 \text { dages arb. } \\
\text { Elevnoter fra } \\
\text { vejledning. } \\
\text { Færdige opgave. }\end{array}$ & $\begin{array}{l}\text { Observation af } 2^{*} \\
\text { online vejledninger } \\
\text { (Zoom). } \\
8^{*} \text { mailkorresponda } \\
\text { ncer. } \\
\text { Dato for } 7 \\
\text { telefonopkald. }\end{array}$ & 2 stk. \\
\hline
\end{tabular}




\begin{tabular}{|c|c|c|c|c|c|c|c|}
\hline 4 & Mira & $\begin{array}{l}\text { Sydsko } \\
\text { len }\end{array}$ & $\begin{array}{l}\text { Genopb } \\
\text { yggelse } \\
\text { af } \\
\text { Rwanda }\end{array}$ & $\begin{array}{l}\text { His. A } \\
\text { og Samf. } \\
\text { A }\end{array}$ & $\begin{array}{l}\text { Opgave instruks. } \\
\text { Elevnoter efter } 7 \\
\text { dages arb. } \\
\text { Elevnoter fra } \\
\text { vejledning. } \\
\text { Færdige opgave. }\end{array}$ & $\begin{array}{l}\text { observation af } 2^{*} \\
\text { online vejledninger } \\
\text { (Zoom). } \\
5^{*} \\
\text { mailkorrespondanc } \\
\text { er. } \\
\text { Dato for } 9 \\
\text { telefonopkald. }\end{array}$ & 2 stk. \\
\hline 5 & Siv & $\begin{array}{l}\text { Vestsk } \\
\text { olen }\end{array}$ & $\begin{array}{l}\text { Harmon } \\
\text { iske } \\
\text { svingnin } \\
\text { ger }\end{array}$ & $\begin{array}{l}\text { Mat. A } \\
\text { og Fys. } \\
\text { A }\end{array}$ & $\begin{array}{l}\text { Opgave instruks. } \\
\text { Elevnoter efter } 3 \\
\text { dages arb. } \\
\text { Elevnoter fra } \\
\text { vejledning. } \\
\text { Færdige opgave. }\end{array}$ & $\begin{array}{l}\text { Observation af } 2^{*} \\
\text { online vejledninger } \\
\text { (Googlemeet, } \\
\text { Messenger). } \\
6^{*} \\
\text { mailkorrespondanc } \\
\text { er. }\end{array}$ & 2 stk. \\
\hline 6 & Sofia & $\begin{array}{l}\text { Vestsk } \\
\text { olen }\end{array}$ & $\begin{array}{l}\text { Terror } \\
\text { med } \\
\text { fokus på } \\
\text { Dirty } \\
\text { Bombs }\end{array}$ & $\begin{array}{l}\text { Samf. B } \\
\text { og Fys. } \\
\text { A }\end{array}$ & $\begin{array}{l}\text { Opgave instruks. } \\
\text { Elevnoter efter } 3 \\
\text { dages arb. } \\
\text { Elevnoter fra } \\
\text { vejledning. } \\
\text { Færdige opgave. }\end{array}$ & $\begin{array}{l}\text { Observation af } 2^{*} \\
\text { online vejledninger } \\
\text { (1 Messenger og } 1 \\
\text { Googlemeet). } \\
6^{*} \\
\text { mailkorrespondanc } \\
\text { er. }\end{array}$ & 1 stk. \\
\hline 7 & Anders & $\begin{array}{l}\text { Vestsk } \\
\text { olen }\end{array}$ & $\begin{array}{l}\text { Aerodyn } \\
\text { amik }\end{array}$ & $\begin{array}{l}\text { Fys. A } \\
\text { og Mat. } \\
\text { A }\end{array}$ & $\begin{array}{l}\text { Opgave instruks. } \\
\text { Elevnoter fra } \\
\text { vejledning. } \\
\text { Færdige opgave. }\end{array}$ & $\begin{array}{l}\text { Observation af } 1 \\
\text { online vejledning } \\
\text { (Zoom). } \\
\text { 1*mailkorresponda } \\
\text { nce. }\end{array}$ & o stk. \\
\hline 8 & Eva & $\begin{array}{l}\text { Østsko } \\
\text { len }\end{array}$ & $\begin{array}{l}\text { Kampen } \\
\text { for } \\
\text { ligestilli } \\
\mathrm{ng}\end{array}$ & $\begin{array}{l}\text { Samf. A } \\
\text { og His. } \\
\text { A }\end{array}$ & $\begin{array}{l}\text { Opgave instruks. } \\
\text { Elevnoter efter } 3 \\
\text { og } 9 \text { dages arb. } \\
\text { Elevnoter fra } \\
\text { vejledning. } \\
\text { Færdige opgave. }\end{array}$ & $\begin{array}{l}\text { Observation af } 2^{*} \\
\text { face-to-face } \\
\text { vejledninger. } \\
6^{*} \\
\text { mailkorrespondanc } \\
\text { er. } \\
\text { Dato for } 2 \\
\text { telefonopkald. }\end{array}$ & 2 stk. \\
\hline 9 & Per & $\begin{array}{l}\text { Østsko } \\
\text { len }\end{array}$ & $\begin{array}{l}\text { Mediern } \\
\text { es magt } \\
\text { og rolle i } \\
\text { demokr } \\
\text { atiet }\end{array}$ & $\begin{array}{l}\text { Samf. A } \\
\text { og } \\
\text { Dansk A }\end{array}$ & $\begin{array}{l}\text { Opgave instruks. } \\
\text { Elevnoter efter } 3 \text {, } \\
7 \text { og } 9 \text { dages arb. } \\
\text { Elevnoter fra } \\
\text { vejledning. } \\
\text { Færdige opgave. }\end{array}$ & $\begin{array}{l}\text { Observation af } 2^{*} \\
\text { face-to-face } \\
\text { vejledninger. } \\
\text { Observation af } 1 \\
\text { vejledning over } \\
\text { facetime. } \\
3^{*} \\
\text { mailkorrespondanc } \\
\text { er. }\end{array}$ & 2 stk. \\
\hline
\end{tabular}

Analysen af den kvalitative data tager afsæt i Riessmans narrative tematiske analysemetode, hvor narrativer forståes som et afgrænset segment af tale, der er tidsligt ordnet og som genfortæller en begivenhedsrækkefølge" (Riessman 2008: 116). Der er tale om en pragmatisk definition, der skal tjene til afgrænsning af narrativer i informanternes fortællinger. Endvidere er analysen inspireret af Franks dialogisk orienterede narrative analysestrategi, som involverer en kontekstualisering af narrativerne og 
dermed lægger op til en analyse på tværs af vejledningshændelserne (Frank 2015: 37). Den dialogisk orienterede narrative analysestrategi fokuserer på, hvordan de enkelte narrativer resonnerer de kontekster de er indlejret i (McAlpine \& Norton 2006), hvilket gør metoden relevant i en undersøgelse af, hvordan vejledningens didaktiske indhold kommunikativt forhandles i den nye online kontekst. Kodningsprocessen var styret af intentionen om at strukturere og få overblik over de temaer, der udkrystalliseredes på tværs af de enkelte cases og på den baggrund få indsigt i, hvordan den personlige vejledningserfaring er indlejret i vejledningskulturen (Bruner 1987; Frank 2015). Kategorierne tid og rum er jf. teoriafsnittet brugt som analysekategorier i en undersøgelse af narrativer, der repræsenterer de tre hyppigst forekommende vejledningsformater i empirien: skriftlig asynkron vejledning (undervisningsplatform og mail), audio synkron (telefon) og video synkron (teams, skype og zoom). Kategorierne giver forklaringskraft til, hvordan brugen af de forskellige virtuelle vejledningsformater påvirker vejledningens indhold, form og funktion.

Tabel 3: Skema til illustration af analysestrategi

\begin{tabular}{|l|l|l|l|}
\hline $\begin{array}{l}\text { Analyseenhed: } \\
\text { formater for } \\
\text { virtuel } \\
\text { vejledning }\end{array}$ & $\begin{array}{l}\text { Emails og andre } \\
\text { virtuelle skriftbårne } \\
\text { kommunikationstråde } \\
\text { (messenger, lectio, sms } \\
\text { mm.) }\end{array}$ & $\begin{array}{l}\text { Audio online } \\
\text { vejledning } \\
\text { (telefonopkald } \\
\text { mm.) }\end{array}$ & $\begin{array}{l}\text { Online vejledning } \\
\text { m. video } \\
\text { (Zoom, teams mm.) }\end{array}$ \\
$\begin{array}{l}\text { / Analysekategori } \\
\text { Tid }\end{array}$ & & & \\
\hline Rum & & & \\
\hline
\end{tabular}

\section{Præsentation af analysens fund}

\section{Udfordringer knyttet til den virtuelle vejledning - Indsigter fra de kvantitative data}

De kvantitative data fra undersøgelsen viser, at når det kommer til spørgsmålet om, hvilke formater der prægede online-vejledningen, var vejledningen præget af stor diversitet (Tabel 4).

Tabel 4: 3.g-elevernes svar på spørgsmålet: "Hvilke medier/platforme er blevet brugt i forbindelse med vejledningen? (du kan sætte flere kryds)"

\begin{tabular}{|l|l|l|}
\hline & Respondenter & Procent \\
\hline Via Skype & 6 & $2,8 \%$ \\
\hline Via Teams & 78 & $36,3 \%$ \\
\hline Via Zoom & 3 & $1,4 \%$ \\
\hline Over telefonen & 51 & $23,7 \%$ \\
\hline Over mail & 60 & $27,9 \%$ \\
\hline Via skolens sædvanlige undervisningsplatform & 96 & $44,7 \%$ \\
\hline Andet: & 70 & $32,6 \%$ \\
\hline
\end{tabular}

Langt størstedelen af eleverne angiver, at de har modtaget vejledning via skolens sædvanlige undervisningsplatform. Dernæst følger Microsoft-platformen Teams, som er en kommunikations- og samarbejdsplatform, der har en applikation til videomøder kombineret med chat og fillagring. Herudover har en stor del modtaget vejledning over mail og pr. telefon. Af det samlede datasæt kan det udledes, at eleverne ikke blot oplever stor variation i brugen af vejledningsformater, men også i 
hyppigheden og omfanget af vejledningshændelser. I det kvalitative datasæt er det kun en enkelt af skolerne, der udmønter vejledningskravet som et krav om brug af et konkret format (Zoom), på et fastsat tidspunkt med et fastlagt omfang. På de øvrige skoler fastlægges valg af formater, tidsrum, deltagere og omfang af de enkelte vejledere, delvist i dialog med eleverne. Der har altså været forskel på, om de kommunikative forhandling alene har fundet sted ift. indholdet af vejledningsprocesserne under hensyntagen til de udstukne rammer, eller om de også har tematiseret rammerne for vejledningen.

De forskellige formater kan være med til at forklare, hvorfor eleverne i surveyen vurderer deres muligheder for at få vejledning så forskelligt (tabel 5).

Tabel 5: 3.g-elevernes svar på spørgsmålet: "Jeg har god mulighed for at få vejledning under arbejdet med min SRP/SOP"

\begin{tabular}{|l|l|l|}
\hline & Respondenter & Procent \\
\hline Slet ikke & 43 & $8,9 \%$ \\
\hline I lav grad & 133 & $27,4 \%$ \\
\hline Hverken i høj eller lav grad & 83 & $17,1 \%$ \\
\hline I nogen grad & 125 & $25,8 \%$ \\
\hline I høj grad & 90 & $18,6 \%$ \\
\hline Ved ikke & 11 & $2,3 \%$ \\
\hline I alt & 485 & $100,0 \%$ \\
\hline
\end{tabular}

Som det fremgår af tabel 5, oplever knap halvdelen af eleverne $(44,4 \%)$ i høj eller nogen grad at have haft god mulighed for vejledning, mens lidt mere end en fjerdedel $(27,4 \%)$ angiver, at det i lav grad var tilfældet, og 8,9\% angiver, at det slet ikke var tilfældet. Analysen af elevernes narrativer omkring disse forhold i de uddybende svar til spørgsmålet om muligheden for vejledning i surveyen gør det klart, at eleverne oplever at have været udfordret på særligt tre forhold, som altså implicit eller eksplicit træder frem som afgørende for vejledningsprocesserne: 1) den personlige kontakt til læreren, 2) muligheden for on-demand-vejledning ved behov herfor og 3) oplevelsen af at være en del af et arbejdsfællesskab med mulighed for peer-to-peer-sparring.

Den første udfordring angår betydningen af den personlige relation til læreren, hvilket bl.a. træder frem i en elevs narrativ om den største udfordring ift. skrivningen, som ifølge narrativet er, at "det ikke har været muligt at have 1-1 vejledning dvs. personlig kontakt". I et andet narrativ uddybes det på den måde, at "Jeg foretrækker helst at det er face to face og at jeg ikke selv som sådan skal "booke" en tid hos min lærer. Der er bare mange nitter ved dette. I stedet for præsentationer, får vi bare powerpoints som er halvt stikord. Det kan vi sku ikke bruge til det store. vil hellere have at personerne så optager sig selv i det mindste og sender en video i stedet." Det er et gennemgående træk i elevernes narrativer, at det har virket upersonligt og måske ligefrem fremmedgørende, at det hele har skullet foregå online. De kvalitative data peger imidlertid på, at de nye virtuelle formater muliggør andre praktikker i kontakten med læreren, som ifølge narrativerne virker befordrende for vejledningen. Disse praktikker knyttes til det private rum og den anderledes tidslighed.

Den anden udfordring angår muligheden for on-demand-vejledning. Dette eksemplificeres i en elevs narrativ, hvoraf det fremgår, at: "Det var meget svært at man ikke kunne mødes med sine lærere og få vejledning. Fx hvis man havde ramt en mur og ikke kunne komme i gang igen". Et andet meget udbredt tema er svar-tiden ifm. spørgsmål, hvor en af eleverne fx skriver, at "Der har været dårlige arbejdsforhold i form af manglende mulighed for ordenlig vejledning. Vejledere svarede ikke i ordenlig tid”. Disse erfaringer hænger sammen med variationen i vejledningens brug af format, tidsrum og omfang. De kvalitative data bidrager i den forbindelse bl.a. med en indsigt i, at nogle elever oplever en større umiddelbar adgang til vejledning i form af fx. telefonhenvendelser, sms og Messenger-opkald. 
Den sidste udfordring, der træder frem som et gennemgående tema i elevernes svar til spørgsmålet om mulighederne for vejledning, er oplevelsen af at være en del af et arbejdsfællesskab. Her viser det sig fx at "problemet opstår i, at du står fuldstændig alene med den; der er begrænset mulighed for vejledning, og oplevelsen af, at du får sparret med andre, er mindre end i en normal hverdag”. Her beskrives en følelse af at stå alene, som går igen i flere elevnarrativer i undersøgelsen. En anden supplerer manglen på fællesskabet med reference til noget, der måske mere ligner peer-to-peer-vejledning, idet narrativet peger på, at "Det er svære at få den direkte vejledning, samt man ikke har den samme mulighed for at spørge klassekammerater osv. til råds". Den kvalitative data understøtter i vidt omfang elevernes oplevelse af dette som en udfordring.

Det kan ikke udelukkes, at en del af de udfordringer, der træder frem, resonnerer den kontekster, de er indlejret i. Eleverne har stået $\mathrm{i}$ en stærkt uvant situation, grundet på den ene side Covid-19 og nedlukningen af samfundet, som for mange elever har bragt usikkerhed og bekymringer med sig, og på den anden side omlægningen til online fjernvejledning, som for mange har været uvant, og som vil kunne forstærke den usikkerhed, der generelt kan knytte sig til arbejdet med de store skriftlige opgaver, der jf. indledningen af mange opfattes som 'kronen på værket'. I afsnittet om tidligere vejledningsforskning pegede vi på, hvordan elevernes tro på egne evner fremhæves som et opmærksomhedspunkt, når vejledningen foregår online og på distance, på den ene side fordi online- og distanceformatet er uvant og dermed kan føre til usikkerhed, på den anden side fordi online- og distanceformatet fordrer en særlig grad af selvregulerede læringsstrategier, som kan knyttes til elevernes grad af self efficacy. Vi får i den konkrete situation indblik i elevernes self efficacy gennem to spørgsmål, hvor eleverne under nedlukningen er blevet bedt om at vurdere, hvordan det går med deres opgaver (jf. Tabel 6 og 7).

Tabel 6: 3.g-elevernes svar på spørgsmålet: "Den nuværende situation er meget udfordrende for mit arbejde med min SRP/SOP"

\begin{tabular}{|l|l|l|}
\hline & Respondenter & Procent \\
\hline Slet ikke & 54 & $11,1 \%$ \\
\hline I lav grad & 66 & $13,6 \%$ \\
\hline Hverken i høj eller lav grad & 75 & $15,5 \%$ \\
\hline I nogen grad & 134 & $27,6 \%$ \\
\hline I høj grad & 144 & $29,7 \%$ \\
\hline Ved ikke & 12 & $2,5 \%$ \\
\hline I alt & 485 & $100,0 \%$ \\
\hline
\end{tabular}

Tabel 7: 3.g-elevernes svar på spørgsmålet: "Jeg er kommet godt i gang med min SRP/SOP"

\begin{tabular}{|l|l|l|}
\hline & Respondenter & Procent \\
\hline Slet ikke & 19 & $3,9 \%$ \\
\hline I lav grad & 42 & $8,7 \%$ \\
\hline Hverken i høj eller lav grad & 61 & $12,6 \%$ \\
\hline I nogen grad & 140 & $28,9 \%$ \\
\hline I høj grad & 198 & $40,8 \%$ \\
\hline Ved ikke & 25 & $5,2 \%$ \\
\hline I alt & 485 & $100,0 \%$ \\
\hline
\end{tabular}

Af Tabel 6 og 7 fremgår det, at over halvdelen af eleverne (57,3\%) oplever situationen som udfordrende for deres arbejde med SRP/SOP, men at en stor del (69,7\%) alligevel oplever at være godt i gang i gang med SRP'en/SOP'en. Man kunne antage, at sidstnævnte skyldes, at eleverne har fået mere tid og ro til at arbejde med deres opgaver under den nationale nedlukning, hvilket korrelerer med data fra survey 
(tabel 8), hvor næsten halvdelen (45,6\%) svarer, at situationen giver dem mere tid til at arbejde med opgaven. Imidlertid er der også næsten en tredjedel (31,7\%), der svarer i lav grad eller slet ikke hertil:

Tabel 8: 3.g-elevernes svar på spørgsmålet: "Den nuværende situation giver mig mere tid til at arbejde med min SRP/SOP"

\begin{tabular}{|l|l|l|}
\hline & Respondenter & Procent \\
\hline Slet ikke & 82 & $16,9 \%$ \\
\hline I lav grad & 72 & $14,8 \%$ \\
\hline $\begin{array}{l}\text { Hverken i høj eller } \\
\text { lav grad }\end{array}$ & 90 & $18,6 \%$ \\
\hline I nogen grad & 128 & $26,4 \%$ \\
\hline I høj grad & 93 & $19,2 \%$ \\
\hline Ved ikke & 20 & $4,1 \%$ \\
\hline I alt & 485 & $100,0 \%$ \\
\hline
\end{tabular}

Billedet af den tredjedel, der ikke oplever, at situationen giver dem mere tid til arbejdet med SRP-/SOPopgaven, nuanceres i de narrativer, der træder frem i surveys åbne spørgsmål. Her forlyder det fx, at "Jeg har ingen tidsfornemmelse, og det er for let at lave alt muligt andet når man alligevel er hjemme. Fuldstændig umuligt at komme i gang, og jeg havde virkelig brug for de forskellige workshops der var planlagt", mens det i et andet narrativ fremhæves, at "Den er okay i forhold til at jeg føler, at jeg har fået mere tid til den. Dog giver alt den ekstra frihed også lidt problemer med at tage sig sammen til at lave den”. Tid forstås således ikke kun i relation til antallet af klokketimer, men i høj grad også ift. tidsfornemmelse og tidshåndtering. Narrativerne skaber altså den fortælling, at den ubegrænsede tidsmængde qua det forhold, at eleverne ikke skal så meget andet, samt den manglende tidsstruktur, udfordrer elevernes tidshåndtering.

Den videre artikels erkendelsesinteresse er rettet mod, hvordan de ændrede vilkår for vejledning, online-vejledningsformaterne, giver andre betingelser for kommunikation og relationer i vejledningshændelserne og i sidste instans påvirker vejledningens didaktiske formål. Fundene fra den narrative tematiske analyse af elevernes fortællinger om vejledning kan give forklaringskraft til, hvordan eleverne oplever at de forskellige virtuelle formater påvirker deres skriveproces.

\section{Når vejledningen foregår i skriftlige kommunikationstråde}

Næsten halvdelen af de adspurgte elever modtog (jævnfør tabel 4) en del af deres vejledning over en skriftlig kommunikationstråd som fx mail, Messenger, Facebook eller beskeder sendt over skolernes kommunikationsplatforme. I et tidsmæssigt perspektiv er denne kommunikationsform kendetegnet ved at være asynkron, idet vejledte og vejleder er adskilt i tid, og henvender sig og besvarer henvendelser på ulige tidspunkter uden viden om, hvornår dialogpartneren læser eller responderer. Tiden, der kommunikeres i, kan således både være tæt knyttet til en samtidighed eller kan foregå over store og ofte diskontinuerlige tidsmæssige spand. Kommunikationsformen præges også af, at deltagerne er adskilt i rum. De kan hverken se eller høre hinanden og har ingen viden om, hvordan deres henvendelse bliver modtaget, ligesom de ikke har adgang til at afkode stemme, mimik og gestik hos dialogpartneren. I de uddybende svar i surveyen viser der sig en udtalt skepsis over denne form for vejledning: "Personlig kontakt gør en forskel ift. mail osv.". Tidsperspektivet træder også frem, når det kommer til den asynkrone skriftlige vejledning, både ift. tilgængelighed: "Lærerne har ikke altid været lige nemme at få vejledning fra over mail" og ift. usamtidighed: "Det var rigtigt svært, når man skrev mails til en vejledere og ikke fik svar før noget tid efter”. Empirien peger dog også på, at de fora der bruges til kommunikationen, alligevel integrerer en form for tids-rumligt codex, som øver indflydelse på den tid, der kommunikeres indenfor og den måde der kommunikeres på i det rum, formatet etablerer. Således kan en hyppigere og mere kontinuerlig kontakt iagttages på platformene Messenger og Facebook. 
Kommunikationen på disse platforme har endvidere en sproglig mere uformel tone, hvilket givetvis kan forstås i lyset af, at det er platforme, som både vejledere og vejledte sædvanligvis benytter i deres private kommunikation. Herved etableres et mere privat og uformelt rum.

Svarene fra survey tematiserer også det mere indholdsmæssige aspekt af den asynkrone skriftlige vejledning. Der er elever, der oplever, at det kan være svært at formulere sig præcist og ikke tilstrækkeligt fyldestgørende omkring de spørgsmål eller problemer, de står med: "Det er ikke så nemt at formulere over for lærerne hvad man præcist tænker i forhold til hvad man har brug for hjælp til, samtidig med at man skal vente længere på svar, end hvis der var en fysisk dialog”, mens der er andre, der beskriver udfordringer, som tematiserer vejledernes svar: "lærere svarede ikke på mail, og når de gjorde, var svarene kortfattede og hjalp ikke det store". Sidst, men ikke mindst er der elever, der føler sig udfordrede ift. værdien af den udveksling, der typisk vil være i en dialog-baseret vejledning:"Mangler fysisk vejledning i stedet for en mail hvor man skal formulere det hele. Og så når man har sendt har man lige flere spørgsmål. Jeg mangler dialog. Det hele er meget svært når man ikke kan se hinandens kropssprog osv."

Hos case-eleverne fra den kvalitative undersøgelse er der både eksempler på elever, der udelukkende vejledes $\mathrm{i}$ et skriftligt vejledningsformat som $\mathrm{fx}$ mail og elever, der modtager den skriftlige online vejledning som et supplement til anden vejledning (tabel 2). Disse to forskellige vilkår afføder to forskellige narrativer om formatet. Eleverne, der udelukkende modtager vejledning i et skriftligt online format, konstruerer et narrativ, der understøtter fundene fra den kvantitative analyse, idet de peger på, at omlægning af vejledning til et online format er en udfordring for dem i forhold til deres faglige udvikling såvel som psykosociale trivsel, hvilket Siv fra Vestskolen fortæller om:

\begin{abstract}
"Elev: Altså jeg har følt en lille smule, at det har været sådan, at jeg skulle stille spørgsmål, og så er de kommet med et svar, men det er jo bare ikke nogen samtale, så jeg ville nok ønske, at det var mere lidt sådan samtale, at de sådan spurgte ind til sådan, hvad kommer jeg ind på i det afsnit og sådan få lidt mere vejledning. Man kunne jo godt have brug for vejledning, selvom man ikke selv ved det sådan... det har kun været vejledning, når jeg har haft et spørgsmål ... og jeg synes også, ja det er også lidt svært, fordi de har jo ikke set noget som helst, jeg har skrevet. Det ville jeg i hvert fald godt have haft, så de mere konkret vidste, hvor jeg var i selve processen. (...) jeg ville nok have ønsket, det er nok lidt lettere, hvis man sådan mødtes og så sad og kiggede på det i stedet, for det ikke var sådan spørgsmål, jeg kunne stille på mail, for det var mere sådan, hvordan jeg kom videre. Det var jo meget hurtigt overstået, altså nogle vejledninger, det var bare sådan to spørgsmål og så svarede de på det... det er lidt sådan det fungerer, det var kun over Messenger beskeder, der var intet sådan videochat eller sådan snakke.
\end{abstract}

Interviewer: Tror du, det havde været anderledes, hvis I havde snakket sammen?

Elev: ja, fordi så vil man... de havde sådan været forpligtet til at sidde der og snakke med mig, så vil de være tvunget sådan lidt mere til en samtale. Man føler ikke rigtig, jeg tror ikke jeg har fået et eneste sådan spørgsmål om, hvordan det går, det var bare, om jeg havde nogen spørgsmål... Ja, jeg ville helt klart have ønsket mig mere sådan samtale om opgaven." (Siv, Vestskolen)

Narrativet illustrerer to centrale forhold, der angår formatets asynkrone tids- og rum-dimension. For det første peges på, at vejledningen drives af elevens spørgsmål, hvor udfordringen er, at eleven finder det svært over mail at stille spørgsmål, der vedrører udlægning af teorier, analyse og sammenhæng. Som en mulig konsekvens af dette retter indholdet af vejledningen sig primært mod formalia i opgaven, og vejledningshændelsens form struktureres af elevinitierede spørgsmål og kort vejlederrespons. Eleven ønsker imidlertid en mere fagligt udviklende dialog, der kan drive skriveprocessen videre, hvilket tydeliggøres ved formuleringer som "samtale om opgaven" og "hjælpe videre". For det andet illustrerer citatet, at eleven knytter nogle psykosociale forventninger til vejledningens indhold og form, idet hun 
har en forventning om, at vejledningens indhold skal adressere hendes skriveproces og spørge til, "hvordan det går". Eleven har også her en oplevelse af, at formen ikke muliggør dette. I begge tilfælde påvirkes vejledningen af den ændrede tids-rumdimension, idet formatet ikke inviterer til en udfoldet tekstnær dialog, men snarere lægger op til spørgsmål og svar, der kan besvares kort.

Rummet lader også til at have betydning for oplevelsen af vejledningen qua fraværet af sansemæssige faktorer knyttet til tilstedeværelse af stemme og krop:

\begin{abstract}
"Der var nogle gange, hvor jeg holdt igen med at spørge om. Jeg synes bare, at det ved jeg ikke, jeg kan godt mærke, at jeg synes det var lidt pinligt og bare fyre en masse spørgsmål af, det virkede bare sådan lidt voldsomt, hvor det ville bare have været så meget lettere, lige at spørge og hvad så lige med det her, altså hvis nu man var sammen... så ja, at man bare havde nogen aftaler med at man lige snakkede sammen... og jeg ved godt, at det skal man også selv søge, og nu går vi i 3.g, så altså at man burde vel selv kunne gøre det... de vil jo gerne hjælpe, men de har jo så mange opgaver, som de sådan skal hjælpe elever med" (Eva, Østskolen)
\end{abstract}

De data der knytter sig til elever, der modtager skriftlig vejledning som et supplement til video eller telefonvejledning, peger imidlertid i retning af en anden fortælling, en fortælling om en vejledning, en vejledning, som de oplever bidrager positivt til deres skriveproces:

\begin{abstract}
"Så tror jeg også mere, jeg har benyttet mig af i den her opgave mere end i de andre opgaver, sådan og stille spørgsmål til dem løbende... altså skrive nogle spørgsmål til dem når de lige dukkede op, fordi der... ja det ved jeg ikke, det følte jeg mere vi at vi kunne i den ... eller kunne... ja det ved jeg ikke, hvad man skal sige, men sådan... der føltes det bare mere naturligt for mig og skrive et spørgsmål til dem, når det lige dukkede op, hvor i de andre opgaver der har jeg nok mere bare kun benyttet mig af den vejledning, der ligesom var sat tid af til." (Luna, Sydskolen)
\end{abstract}

Citatet illustrerer, at denne vejledning knytter sig tæt til elevens skriveproces og adresserer spørgsmål, der opstår i skriveprocessen, hvilket man bl.a. ser med vendinger som "når det lige dukkede op" og "løbende stille spørgsmål". Af datamaterialet (udskrifter af de skriftlige kommunikationstråde), fremgår det, at indholdet i dette vejledningsformat typisk angår formalia, materialeforespørgsler eller omhandler opgaveelementer, hvor eleven gerne vil bekræftes i, at han/hun har forstået det korrekt. Fra elevens perspektiv har formatet den styrke, at det er karakteriseret ved en umiddelbar tilgængelighed, og dermed en hurtig hjælp, så hun kan komme videre med skriveprocessen.

\title{
Når vejledning foregår gennem audiobaserede opkald
}

Knap en fjerdedel af de adspurgte elever modtager audiobaseret vejledning, dvs. opkald over Messenger eller telefon, som kun har adgang til lyd (tabel 4). Kommunikationen er her knyttet til en synkron tid, hvor det er af særlig betydning, at vejleder er tilgængelig for eleven. Der er ikke direkte adgang til de rum dialogparterne befinder sig i, hvorfor det sansemæssige indtryk, der kan knyttes til vejledningen, er stemmebåren. Alligevel er det vejledningsrum, der etableres i samtalen, knyttet til en form for privat intimsfære, idet dialogparterne befinder sig i deres privatsfære, det hjemlige, som dialogpartneren qua opkaldet inviteres ind i. Elevernes oplevelse af dette format er flertydigt. Af de uddybende svar til survey fremgår det blandt andet, at "Det kan være svært at få en fyldestgørende vejledning fra sine vejledere, når der ikke er mulighed for at mødes fysisk. En telefonsamtale eller et delt dokument i Google Drev giver ikke de samme muligheder som en samtale i samme rum." Citatet udpeger en udfordring i forhold til vejledningens indholdsmæssige dimension og knytter det til den personlige kontakt til læreren, hvor adskillelsen i rum opleves som en barriere. Samtidig peger citatet på, at adskillelsen i rum påvirker elevens forståelse af vejledningshændelsens indhold. Endvidere er det værd at fremhæve, at den audiosynkrone vejledning beskrives som særligt udfordrende af en elev med dysleksi: “da jeg skrev SSO havde 
man ikke den fysiske kontakt og kommunikation med underviser og kammerater og for en ordblind er det hårdt at sidde med alt på skift og ingen kommunikation udover på tlf.". Citaterne, ikke mindst det sidste, giver anledning til at overveje, om den audio-synkrone vejledning kan stå for sig selv eller om eleverne oplever et større udbytte, når den suppleres af de øvrige vejledningsformater. Analysen af de kvalitative data bidrager til at belyse dette aspekt yderligere.

I det kvalitative casestudie er fire elever vejledt i det audio-synkrone format, og elevernes fortællinger illustrerer, at de oplever at dette vejledningsformat har værdi for deres skriveproces:

\footnotetext{
"Jeg synes faktisk, at det har været fedt at have online vejledning på en eller anden måde. Det der med at jeg bare kunne.... altså jeg har kunnet ringe til dem stort set hele tiden, når jeg har haft et eller andet spørgsmål. Og så har man, altså så har man været i det, når man var der... fordi havde vi siddet til vejledning oppe på skolen i klasser og skullet skrive og sådan noget, så har man ikke den samme, hvad skal man sige... alene tid med læreren, fordi der står en elev ved siden af og godt lige vil have noget hjælp også. Det var lidt rarere at have, at have $\mathrm{X}$ under sådan lidt mere uformelle... lidt mere uformelle forhold (...) det betyder jo enormt meget, at der er en, der tror på, man kan gøre det her, og som interesserer sig for ens udvikling og at gøre en bedre og ... hvad skal man sige... altså der virkelig viser, at de lægger noget i det, og er sat ind i ens emne." (Mira, Sydskolen)
}

Elevernes positive oplevelse af vejledningsformatet angår både den personlige kontakt til læreren og muligheden for on-demand vejledning. Begge forhold adresserer vejledningens tids- og rum-dimension. For det første fortælles om stor tilgængelighed i forhold til vejledningen, eleverne kan i høj grad opsøge og modtage vejledning, når behovet opstår. Endvidere fortæller eleverne, at fordi formatet ikke rammesættes fra organisationens side, er der en oplevelse af at have god tid i vejledningen. Den positive oplevelse kan også forklares gennem de rumlige dimensioner. Eleverne oplever at vejledningsrummet er uformelt, hvilket knyttes til telefonopkaldets mere spontane karakter. Endvidere fortæller eleverne om at byde vejlederen ind i og blive budt ind i privatsfæren, hvilket de knytter sammen med en psykosocial erfaring af, at vejleder udviser oprigtig interesse, at eleven "bliver set og hørt". At det anses som et privilegium, er naturligvis knyttet til en positiv oplevelse af vejledningsrelationen, hvilket er et genkommende træk i elevens oplevelse af kvaliteten i "alene tid med læreren”. Når man undersøger indholdet af vejledningen i dette vejledningsformat, er det knyttet til en bekræftelse af eleven, fx i forhold til om han/hun handler i overensstemmelse med opgavekravene. Endvidere er det et genkommende træk, at eleverne i høj grad bruger samtalen til at afprøve formuleringer, som de så kan blive be- eller afkræftet i. Det er således i stort omfang den psykosociale dimension, der er fremtrædende i dette vejledningsformat. Materialet viser ikke en vejledning, der knytter an til tekstlige forlæg fra eleven, men opkaldene er i flere tilfælde initieret af, at eleven forud for samtalen har sendt et skriftligt spørgsmål til vejleder, som vejleder finder det hensigtsmæssigt at uddybe mundtligt.

\section{Når vejledning foregår gennem online videomøder}

En betydelig del, knap 40\%, af eleverne, afvikler en del af deres vejledning ved brug af et online-videoformat som fx Zoom, Teams, Google-meet og Skype (tabel 2). I en kontekst af tid, er kommunikationen på disse platforme karakteriseret ved at være synkron, hvorved dialogen er knyttet til en samtidighed og dermed også en spontanitet i dialogen. Kommunikationen i vejledningsrummet er kendetegnet ved, at dialogparterne befinder sig i adskilte rum, men oftest med adgang til hinandens rum via kamera. Dialogparterne lukkes på denne vis delvist ind i hinandens privatsfærer. Denne dialogform understøttes af sansemæssige indtryk som fx stemme, mimik og kropssprog.

Af kommentarerne i survey kan man udlede, at online-video formatet typisk ikke har inddraget elevproduceret tekst. Kritikken af vejledningen retter sig i høj grad mod indholdsdimensionen: "Det er udfordrende, da vi ikke har haft mulighed for at få face-to-face hjælp af ens vejledere. Det har været 
besværligt at skulle forklare noget i ens SRP mundtligt, når det klart ville være en fordel at vise/pege, når man var i tvivl om noget." Udsagnet peger direkte på fraværet af skriften som et fælles udgangspunkt for dialogen. Analysen af de kvalitative data understøtter dette, men samtidig leverer det også andre perspektiver, idet nogle af eleverne netop har benyttet sig af de muligheder for at inddrage skrift ved hjælp af skærmdeling, som formatet rent faktisk rummer.

Tre af eleverne fra den kvalitative undersøgelse har modtaget video-baseret online-vejledning, og empirien giver anledning til at reflektere over, hvordan tid og rum indvirker på både form og indhold. De tre elever understreger alle, at formatet bidrager til en form, hvor de oplever, at der "er ro på":

\begin{abstract}
"Man [har] ikke følt, at man skulle forhaste sig afsted på nogle områder, fordi hvis man sidder ovre på skolen, så kan man godt blive lidt distraheret af, at der går folk rundt og venter p̊̊, at nu er det deres tur og sådan noget. Her der ville det ikke gøre noget, hvis man måske gik to minutter tre minutter over tid og så altså..... computeren havde de jo til rådighed hele tiden, så det med at man bare kunne kontakte dem sådan på den måde hele tiden, det tror jeg måske, har gjort det lidt bedre ja." (Sofia, Vestskolen)
\end{abstract}

Eleverne bliver mødt på hjemmebane, og de oplever både en høj grad af tilgængelighed, og at der er god tid til samtale i det vejledningsrum, de etablerer med vejlederne. Dette understøttes af observationerne, hvor man ser et vejledningsrum præget af en afslappet stemning og en dialog, der veksler mellem det faglige og det personlige. På indholdssiden gælder det for alle vejledninger, at de adresserer det faglige engagement såvel som det psykosociale. Det psykosociale adresseres gennem en omsorgsdiskurs "hvordan går så?” "har du styr på det?” "har du det godt?”. Den faglige dialog initieres typisk af vejleders spørgsmål om, hvad eleven har brug for hjælp til. Størstedelen af de problemfelter, eleverne adresserer, knytter sig imidlertid til formalia, genre, begrebsbrug eller litteraturbrug, hvorfor vejledningen kun i begrænset udstrækning adresserer sammenhæng og argumentation på tekst-niveau. Dette forhold kan give forklaringskraft til, at eleverne fra survey-undersøgelsen ikke oplever et udbytte af vejledningen, som modsvarer deres forventninger til den faglige dialog. En enkelt at de afholdte vejledninger adskiller sig imidlertid fra det øvrige materiale, idet vejledningen baseres på et tekstforlæg fra eleven:

\begin{abstract}
"Altså han [samfundsfagslæreren] har hjulpet mig rigtig meget med at formulere tingene, han har også, da jeg var færdig med min redegørelse, der sendte jeg den til ham, og så læste han den igennem, og kommenterede på nogle ting, altså så havde jeg skrevet den, og så sendte jeg den til ham, og så havde vi en [virtuel] vejledning, hvor at han gennemgik den med mig, og sagde, hvad der var godt, og hvad der var mindre godt, og hvad jeg skulle måske have lidt mere af og altså sådan lidt på den måde." (Sofia, Vestskolen)
\end{abstract}

Formen får her betydning for indholdet af vejledningssekvensen, idet det tekstmæssige forlæg afstedkommer en faglig dialog med afsæt i elevens tekstforlæg. Med afsæt i den konkrete tekst taler elev og vejleder om, hvad der fungerer og hvad der skal arbejdes videre med. På den vis er vejledningen rette mod en faglig substans, som begge parter kan indgå i en dialog omkring, og som kan drive elevens skriveproces videre. Det er bemærkelsesværdigt, at online-video vejledning kun i så begrænset omfang benytter sig af inddragelse af tekstlige forlæg, når formatet rummer muligheden for det.

\title{
Vurdering
}

Analyserne viser, at elevernes narrativer antager to spor i oplevelsen af, hvordan den virtuelle vejledningshændelse kvalificerer arbejdet med deres opgave. På den ene side er der et ønske om, at indholdet har et fagligt fokus, at eleverne får besvaret konkrete spørgsmål og at vejledningen samtidig bidrager til en faglig udvikling. På den anden side fylder den psykosociale dimension meget i elevernes fortællinger om, hvordan online vejledning understøtter arbejdet med opgaven. Her viser empirien, at eleverne har et stort behov for at blive bekræftet $\mathrm{i}$, at de er på rette vej. Ligeledes har de et udtalt ønske 
om tilgængelighed i vejledningen, vejledning on-demand. Analysen har vist, hvordan de to spor adresseres i elevernes oplevelser af de forskellige vejledningsformater, og den har vist, at eleverne både oplever nærvær og fleksibilitet samt distance og manglende fleksibilitet. Dette knytter sig ikke nødvendigvis til det anvendte vejledningsformat, men er også forbundet med elevtyper og vejlederes forskellige præferencer. For både den faglige og den psykosociale dimension gælder det imidlertid, at eleverne har et ønske om, at den virtuelle vejledning etablerer oplevelsen af et tids-rumligt nærvær og at vejledningen knyttes tættere til deres skrivning og deres skriveproces.

Med analyserne kan vi pege på, at der er knyttet et stort potentiale til brugen af de forskellige online vejledningsformater. Der lader dog til at være en uoverensstemmelse mellem de formål eleverne knytter til de forskellige formater og de praktikker, vi kan udlede af vejledningshændelserne. Analyserne indikerer, at uoverensstemmelsen kan knyttes til en manglende didaktisk bevidsthed om, hvad de forskellige virtuelle vejledningsformater kan bidrage med og det peger på betydningen af at afstemme forventninger og tydeliggøre aftaler. Med den kommunikative tilgang har vi kunnet pege på, at de ændrede vilkår i tid og rum, som gør sig gældende, når vejledning flytter sig fra den fysiske face-to-face vejledning til vejledning online, har stor betydning for, hvilket virtuelt format det er hensigtsmæssigt at bruge på forskellige tidspunkter i elevernes opgaveskrivningsproces. Dette giver anledning til at udpege nogle opmærksomhedspunkter for organisationer og vejledere, som det er hensigtsmæssigt at reflektere over i arbejdet med online vejledning:

* Har organisationen en strategi for, hvilke virtuelle vejledningsformater det er hensigtsmæssigt at bruge i hvilke sammenhænge?

* Har vejleder viden om, hvilke vejledningsformater det er hensigtsmæssigt at bruge i den konkrete vejledningssituation?

* Er der aftaler mellem vejleder og vejledte, som forholder sig til bl.a. adgang til vejledning, hyppighed, vejledningstidspunkter, varighed og brug af vejledningsformat?

* Hvordan kan tekstudkast fra eleven indgå i online-vejledning?

* Er der hos vejleder en bevidsthed om værdien af den faglige såvel som den psykosociale dimension i online-vejledning?

\section{Referencer}

Al Fadda, H. (2019). The Relationship between Self-Regulations and Online Learning in an ESL Blended Learning Context. English Language Teaching, 12(6), 87-93

Anthony, K. \& Nagel, DM (2010). Therapy Online. A practical guide. SAGE

Aspen Institute (2020). State Actions to Support Social, Emotional, and Academic Development: Fostering Connectedness in the Pandemic Era. Education \& Society Program

Beer, M.; Mason, R. B. (2009) Using a blended approach to facilitate postgraduate supervision, Innovations in Education and Teaching International, 46:2, 213-226, DOI: 10.1080/14703290902843984

Bengtsen, S.;Jensen, G. (2015). Online supervision at the university - A comparative study of supervision on student assignments face-to-face and online. Tidsskriftet Læring Og Medier (LOM), 8(13): https://doi.org/10.7146/lom.v8i13.19381

Boud, D.;Lee, A. (2005). 'Peer Learning' as Pedagogic Discourse for Research Education. Studies in Higher Education 30: 501-16. doi: 10.1080/03075070500249138

Bruner, J. (1987). Life as Narrative. Social Research 54:11-32.

Bryman, Alan. 2006. Integrating quantitative and qualitative research: How is it done? Qualitative Research 6: 97-113.

Butcher, J. (2020): Public-Private Virtual-School Partnerships and Federal Flexibility for Schools during COVID19 (March 25, 2020). Special Edition Policy Brief. Retrieved March 26, 2021 from https://ssrn.com/abstract $=3564504$ 
Christensen, T.S.; Elf., N. \& Krogh, E. (2014). Skrivekulturer i folkeskolens niende klasse. Odense: Syddansk Universitetsforlag

Chung, L.-Y. (2015). Exploring the Effectiveness of Self-Regulated Learning in Massive Open Online Courses on Non-Native English Speakers. International Journal of Distance Education Technologies 13(3): 61-73

Clancy, D. S. \& Sentance, M. (2020). Keeping Students Academically Engaged during the Coronavirus Crisis. Pioneer Institute for Public Policy Research. Retrieved December 23, 2020 from https://pioneerinstitute.org/pioneer-research/academic-standards-pioneer-research/keeping-studentsacademically-engaged-during-the-coronavirus-crisis-part-one/.

Crawford, L. M., Randolph, J. J., \& Yob, I. M. (2014). Theoretical development, factorial validity, and reliability of the online graduate mentoring scale. Mentoring \& Tutoring: Partnership in Learning, 22(1), 20-37.

Creswell, J.W. (2017). Qualitative Inquiry \& Research Design: Choosing among Five Approaches. Thousand Oaks, CA: Sage

Dysthe, O.; Samara, A.; Westrheim, K. (2006). Multivoiced supervision of Master's students: A case study of alternative supervision practices in higher education. Studies in Higher Education 31(3): 299-318

Elf, N.; Petersen, C.K. \& Qvortrup, A. (2018). Digitalisering i de gymnasiale uddannelser - status 2017. Gympæd 2.0 20: $22-25$

Erichsen, E. A.; Bolliger, D. U.; Halupa, C. (2014). Student Satisfaction with Graduate Supervision in Doctoral Programs Primarily Delivered in Distance Education Settings. Studies in Higher Education, 39 (2): 321-338

Frank, A. W. (2015). Selves, Holding Their Own with Illness. Creative Dialogues: Narrative and Medicine, edited by I. Fernandes et al. Cambridge Scholars Publishing, 2015, pp. 120-129.

Gatfield, T. 2005. An Investigation into PhD Supervisory Management Styles: Development of a Dynamic Conceptual Model and its Managerial Implications. Journal of Higher Education Policy and Management 27: 311-25. doi: 10.1080/13600800500283585

Geertz, C. (1973). The interpretation of cultures: selected essays. New York: Basic Books.

Greene, Jennifer C. 2007. Mixed methods in social inquiry. San Francisco: Jossey-Bass.

Greene, Jennifer C., Valerie J. Caracelli, and Wendy F. Graham. 1989. Toward a conceptual framework for mixedmethod evaluation designs. Educational Evaluation and Policy Analysis 11: 255-274

Halse, C.; Malfroy, J. (2010). Retheorizing doctoral supervision as professional work, Studies in Higher Education, 35:1: 79-92: DOI: 10.1080/03075070902906798

Hamilton, B. A., \& Scandura, T. A. (2003). E-mentoring: Implications for organizational learning and development in a wired world. Organizational Dynamics, 31(4), 388-402.

Ives, G.;Rowley, G. (2005) Supervisor selection or allocation and continuity of supervision: Ph.D. students' progress and outcomes, Studies in Higher Education, 30:5, 535-555, DOI: 10.1080/03075070500249161

Krogh, E. (2003). Et fag i moderniteten. Danskfagets didaktiske diskurser. Ph.d.-afhandling. Dansk Institut for Gymnasiepædagogik. Syddansk Universitet

Krogh, E. (2006). Danskfaget i moderniteten. I Ongstad, S. (red.). Fag og didaktikk i lærerutdanning. Kunnskap i grenseland. Oslo: Universitetsforlaget

Kumar, S.; Johnson, M. (2017). Mentoring doctoral students online: mentor strategies and challenges. Mentoring and Tutoring: Partnership in Learning, 25(2), 202-222

Kumar, S.; Johnson, M (2019). Online mentoring of dissertations: the role of structure and support, Studies in Higher Education, 44:1, 59-71: DOI: 10.1080/03075079.2017.1337736

Lee, A. 2008. How are Doctoral Students Supervised? Concepts of Doctoral Research Supervision. Studies in Higher Education 33: 267-81. doi: 10.1080/03075070802049202

Leners, D.W, Sitzman, K. Graduate student perceptions: feeling the passion of caring online. Nurs Educ Perspect. 2006 Nov-Dec;27(6):315-9.

Lillis, T. (2009). Bringing Writers' Voices to Writing Research: Talk around Texts. I Carter, A., Lillis, T. \& Parkin, S. (red.). Why Writing Matters: Issues of Access and Identity in Writing Research and Pedagogy. Studies in Written Language and Literacy, 12 (169-187). Amsterdam: Benjamins.

Læreplan Studieområdet - hhx 2017: https://www.uvm.dk/-/media/filer/uvm/gym-laereplaner2017/hhx/studieomraadet-hhx-august-2017-ua.pdf

Læreplan Studieområdet - htx 2017: https://www.uvm.dk/-/media/filer/uvm/gym-laereplaner2017/htx/studieomraadet-htx-august-2017-ua.pdf

Læreplan Studieretningsprojektet - stx 2017: https://www.uvm.dk/-/media/filer/uvm/gym-laereplaner2017/stx/studieretningsprojektet-stx-august-2017-ua.pdf

Maor, D., Ensor, J,; Fraser, B. (2015), Doctoral supervision in virtual spaces: A review of research of web-based tools to develop collaborative supervision. Higher Education Research and Development, 35(1), 172-188: doi: 10.1080/07293360.2015.1121206 
Maxwell, T.W.; Smyth, R. (2011). Higher Degrees Research Supervision: From Practice towards Theory. Higher Education Research and Development 30(2), 219-231

McAlpine, L. \& Norton, J. (2006). Reframing our approach to doctoral programs: an integrative framework for action and research. Higher Education Research \& Development, 25 (1), 317, doi: 10.1080/07294360500453012

McGuinness, C. (2020). Educating at a Distance: A Redistribution of Roles. Retrieved December 23, 2020 from https://epale.ec.europa.eu/sites/default/files/ase.pdf

Ongstad, S. (2006). Fag i endring. Om didaktiktisering af kunnskap. I Ongstad, S. (red.). Fag og didaktikk i lærerutdanning. Kunnskap i grenseland. Oslo: Universitetsforlaget

Park, C. (2005). War of Attrition: Patterns of non-completion amongst postgraduate research students. Higher Education Review, 38(1), 48-53.

Peck, L.; Stefaniak, J. E. \& Shah, S. J. (2018). The Correlation of Self-Regulation and Motivation with Retention and Attrition in Distance Education. Quarterly Review of Distance Education, 19(3), 1-15

Power, M.; Vaughan, N.(2010). Redesigning Online Learning for International Graduate Seminar Delivery. Journal of Distance Education = Revue de L'enseignement à Distance, 24(2).

Qvortrup, A. (2018). Dialogen mellem almendidaktik og fagdidaktik - komplementaritet og eklekticisme som didaktiske kernebegreber. I Christensen, T.; Elf, N.; Hobel, P.; Qvortrup, A. \& Troelsen, S. (red.). Didaktik i udvikling (s. 29-43). Århus: Klim

Qvortrup, A. (2020a). Gymnasiet anno 2019. I Qvortrup, A. (red.). Gymnasiet i udvikling (s. 19-46). København: Hans Reitzels forlag

Qvortrup, A. (2020b). Gymnasiet i den historiske Corona-tid - et elevperspektiv: https://www.sdu.dk//media/files/om_sdu/institutter/ikv/centre/cfs/rapport.pdf

Qvortrup, A.; Zeuner, L. \& Raae, P.H. (2017). Vejen til reformen 2017 - reformeringsprocesser i gymnasiet. Gympæd 2.0 17: 8-11

Rademaker, L. L., Duffy, J., Wetzler, E., \& Zaikina-Montgomery, H. (2016). Chair perceptions of trust between mentor and mentee in online doctoral dissertation mentoring. Online Learning, 20(1), 1-13. Retrieved from https://eric.ed.gov/?id=EJ1096384

Riessman, C.K. (2008). Narrative Methods for the Human Sciences. Thousand Oaks, CA: Sage.

Tladi, L. S. (2017). Perceived Ability and Success: Which Self-Efficacy Measures Matter? A Distance Learning Perspective. Open Learning, 32(3), 243-261

Vejledning Studieretningsprojektet - stx 2020: https://www.uvm.dk/-/media/filer/uvm/gym-vejledninger-tillaereplaner/stx/201028-studieretningsprojektet-stx-vejledning-ua.pdf

Vejledning Studieområdet - hhx 2020: https://www.uvm.dk/-/media/filer/uvm/gym-vejledninger-tillaereplaner/hhx/201026-studieområdet-hhx-vejledning-oktober-2020.pdf

Vejledning Studieområdet - htx 2019: https://www.uvm.dk/-/media/filer/uvm/gym-laereplaner2017/htx/studieomraadet-htx-vejledning-marts-2019-ua.pdf

Wang, Y.; Peng, H.; Huang, R.; Hou, Y. \& Wang, J. (2008). Characteristics of Distance Learners: Research on Relationships of Learning Motivation, Learning Strategy, Self-Efficacy, Attribution and Learning Result. Open Learning, 23(1), 17-28

Wichmann-Hansen, G.; Eika, B.;Mørcke, A. M. (2007). Hvad findes der af litteratur om vejledning? Litteratursøgning med fokus på publicerede, evidensbaserede studier. Dansk Universitetspædagogisk Tidsskrift, 2(3), 11-19: https://tidsskrift.dk/dut/article/view/5636

Wisker, G. (2005). The good supervisor. Basingstoke: Palgrave Macmillan.

Yob, I., Crawford, L. (2012). Conceptual framework for mentoring doctoral students. HLRC. Higher Learning Research Communications, 2(2), 34-47.

Yao, J.; Rao, J.; Jiang, T. \& Xiong, C. (2020): What Role Should Teachers Play in Online Teaching during the COVID-19 Pandemic? Evidence from China (March 31, 2020). Sci Insigt Edu Front 2020; 5(2), 517-524. Retrieved March 26, 2021 from: https://ssrn.com/abstract=3565608

Yin, R. K. (2003). Case Study Research, Design and Methods, Third Edition. Thousand Oaks, California: Sage Publications 


\section{Forfattere}

\section{Anne Bang-Larsen}

Ph.d.-stipendiat

Institut for Kulturvidenskaber, Syddansk Universitet

anneb@sdu.dk

\section{Ane Qvortrup}

\section{Professor}

Institut for Kulturvidenskaber, Syddansk Universitet

Center for Gymnasieforskning

anq@sdu.dk
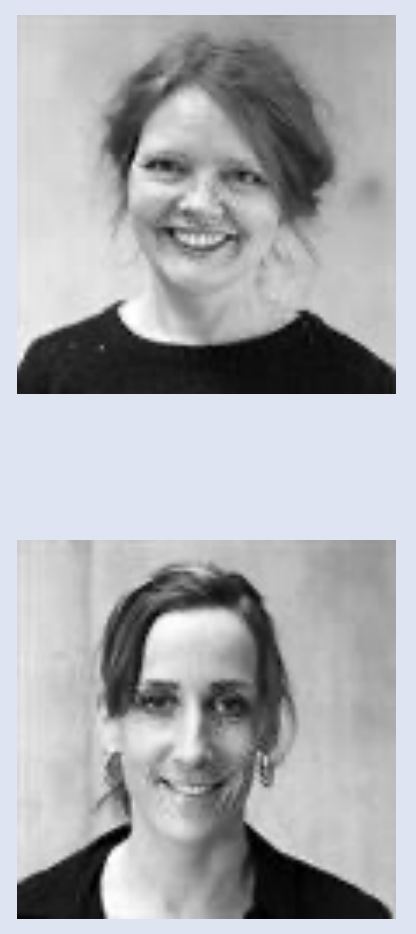

${ }^{1}$ Jf. "Læreplan Studieretningsprojektet - stx 2017" og "Vejledning Studieretningsprojektet - stx 2020",

"Læreplan Studieområdet - hhx 2017" og "Vejledning Studieområdet - hhx 2020" samt "Læreplan

Studieområdet - htx 2017" og "Vejledning Studieområdet - htx 2019".

${ }^{2}$ Empirien indgår i et større ph.d.-studie af elevernes vejledningsforløb i det 3-årige stx-forløb. 